\title{
Data Collection Instrument
}

National Cancer Institute

\section{Source}

National Cancer Institute. Data Collection Instrument. NCI Thesaurus. Code C142472.

An electronic or hard copy mechanism used to collect and assemble clinical information. 